\section{British science}

\section{Sir Keith Joseph regrets . . .}

IT would have been "preferable" if the great cutback of British universities since 1981 could have "gone more gently", according to Sir Keith Joseph, Secretary of State for Education and Science for the past five years. Sir Keith, just now, is in a reflective mood. Ten days ago, he announced that he would not run for reelection to the House of Commons, where he has represented a Yorkshire constituency since 1956. But in an interview last week, he denied newspaper reports that he would leave his present post before the next general election, which must be held sometime in the next 27 months, saying that that is "entirely up to her", a reference to the Prime Minister, Mrs Margaret Thatcher.

Joseph is also unrepentant. Five years ago, he said, the British academic establishment was in need of "jolts". "We inherited massive overspending on research", while the universities were "snobbishly" disdainful of "trade". The result of the 8.5 per cent reduction of university budgets, Sir Keith insisted, was that some universities are now much better than they had been. He claimed some credit for having persuaded Sir Edward Parkes, chairman of the University Grants Committee when the budget reductions were enforced, to admit as much in public.

But have not other universities been damaged? Sir Keith acknowledges that academic morale may be at a low ebb, but insists that it is not yet appreciated in Britain that there is "no god-given right" to suppose that even the present level of prosperity in Britain can be sustained. The government is, however, worried about the loss of bright young scientist from Britain, and awaits with interest and anxiety the Royal Society report on the subject due in the early summer.

Sir Keith lists the causes of the emigration now under way as the invidious comparison between Britain and other countries in respect of salaries, equipment and the chance that good research proposals will be supported by the grant-making agencies, and says he thinks the last may be the most important. He did not last week include in his list the greater intellectual stimulation now to be found at universities outside Britain.

Sir Keith is known to be the chief monetarist influence on the present British government. Indeed, he is proud of having given 150 talks at universities in the two years before the 1979 election on "the moral case for capitalism", running into rowdy trouble on only six occasions. "D'you know", he says, "I went into politics because I wanted to get rid of poverty?".

Now, with the economic "chickens coming home to roost" in Britain, "what we need are flocks and flocks of entrepreneurs". Sir Keith asks for agreement to that proposition (which is given) and to the proposition that the universities cannot produce them (which is withheld). There follows a scrappy conversation about the changing climate in British universities, and the reasons for the economic

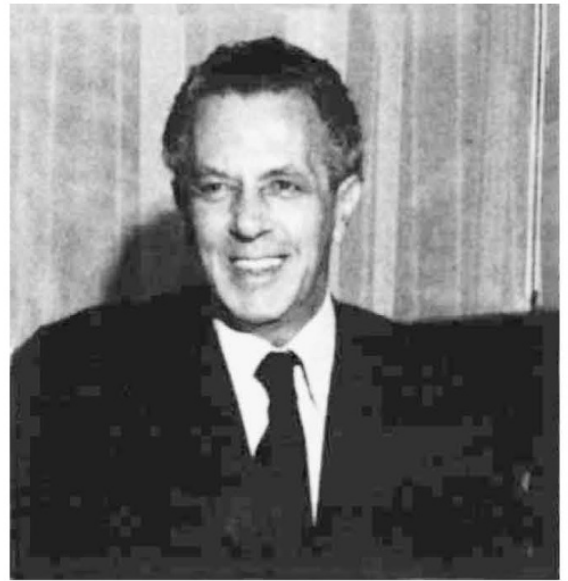

success of the United States and Japan. Sir Keith seems to be advancing two contradictory propositions, that universities cannot, because of their constitution, be a prolific source of enterprise, but that, until they are, they will not be dealt with kindly.

On one specific point, the argument of the Committee of Vice-chancellors and Principals that the demand for student places seems more buoyant than the government's demographic projections, and will be further increased if Sir Keith's own plans for improvement in the schools succeed (see Nature 319, 348; 1986), the minister appears more willing to contemplate a re-expansion of British universities than previous statements would suggest. But he does not think that his plans for better schools will yield increased demand for higher education at least until the 1990 s, which is probably a prudent calculation given the continuing conflict between the government and the teachers' labour unions.

On another point, Sir Keith admits failure. He points out that he has been publicly at odds with his colleagues in the government about the introduction of a scheme for suporting students at universities by means of loans. Such schemes work well elsewhere, he says; he still regrets the "honourable paternalism" and the fear that students from less prosperous backgrounds would be discouraged from seeking higher education, which appear to have been the chief reasons why the government backed away from student loans. Meanwhile, nothing seems to be happening to meet the vice-chancellors' com- plaint about the impoverishment of students and their families.

That complaint is one of the many critical responses to the government's discussion paper on higher education, published a year ago. Sir Keith appears to be a little chastened by the reaction to the document. "If I got the tone wrong, that's my fault." But he resents having been called a "barbarian" on account of it.

So is there any way in which the universities in Britain might work their way back into the government's good books? The minister offers three tests - the abandonment of homogeneous salary scales for academics (which he says he has already brought up with university representatives), the abolition of tenure (and "you know what we are doing about that") and the pursuit of rigour in the universities (to which end the universities' current examination of academic standards will contribute).

Much of what applies to the universities applies to Sir Keith's views of publicly supported research in Britain. Again, it would have been preferable that the "financial adjustments" required of the research councils had been spread over, say, a five-year period. Again, it would help if there were better links, both ways, with the outside world and with industry in particular. There is a case for a science minister, but not an overwhelming (or, one gathers, a persuasive) case. There is no reason to think, he says, that matters such as the British membership of the European high-energy physics community (CERN), or the question of the privatization of the Plant Breeding Institute, would have been settled any more quickly if there had been a minister responsible for getting things done.

In private, it is known that Sir Keith Joseph has in recent years been fighting hard to preserve the publicly supported research base in Britain. Aloud, he remarks on the anomaly that, when his postbag was full of letters from parents protesting at his scheme for raiding the budget for student support in the interests of research (at the end of 1984), he found only one letter of thanks from a scientist. Looking back on his time in his present office, he says with pride that he is glad to have identified a number of problems of national importance (to the British); plainly, he also regrets not having done more to solve them.

So what can the research community in Britain do to win back the support of the government? No doubt a strong show of entrepreneurship would go a long way to meet Sir Kieth's demands. But he himself offers an unexptected suggestion; why not win friends in the House of Commons? Perhaps he is feeling more lonely there now than when the government to which he belongs came to office six years ago.

John Maddox 